\title{
PERMAINAN BOLA VOLI MINI DENGAN MODIVIKASI UNTUK MENINGKATKAN HASIL BELAJAR SISWA KELAS X IPA 2 DI SMA NEGERI 1 PASIR PENYU KABUPATEN INDRAGIRI HULU
}

\author{
JASRUL \\ SMA Negeri 1 Pasir Penyu Kabupaten Indragiri Hulu \\ e-mail: jasrul07@gmail.com
}

\begin{abstract}
ABSTRAK
Jenis penelitian yang dilakukan adalah Penelitian Tindakan Kelas (PTK). Tujuan dari Penelitian Tindakan Kelas (PTK) ini adalah untuk mengetahui penggunaan modifikasi pada pembelajaran permainan bola voli mini untuk meningkatkan hasil belajar siswa kelas X IPA 2 di SMA Negeri 1 Pasir Penyu Kabupaten Indragiri Hulu. Prosedur dalam Penelitian Tindakan Kelas (PTK) ini dilakukan dalam 2 siklus yang dimulai dari siklus I diantaranya tahap persiapan, tahap pelaksanaan, observasi dan refleksi. Pada siklus II yaitu perencanaan dan pelaksanaan, tahapan pada siklus II tidak jauh berbeda dengan tahapan pada siklus I, hanya saja kekurangan pada siklus 1 diharapkan dapat diperbaiki pada siklus II. Hasil penelitian tindakan ini menunjukkan bahwa adanya peningkatan hasil belajar siswa pada mata pelajaran penjaskes dari sebelumnya ke siklus pertama rata-rata 7,12 dan ke siklus kedua rata-rata 7,46 dengan silisih point sebesar 0,34 menunjukkan bahwa penerapan modifikasi alat permainan dapat meningkatkan hasil belajar permainan bola voli mini siswa kelas X IPA 2 di SMA Negeri 1 Pasir Kabupaten Indragiri Hulu Tahun Pelajaran 2021/2022.
\end{abstract}

Kata Kunci: Permainan bola voli mini, modivikasi, hasil belajar

\section{ABSTRACT}

The type of research conducted is Classroom Action Research (CAR). The purpose of this Classroom Action Research (CAR) is to determine the use of modifications in learning mini volleyball games to improve student learning outcomes for class X IPA 2 at SMA Negeri 1 Pasir Turtle, Indragiri Hulu Regency. The procedure in Classroom Action Research (CAR) is carried out in 2 cycles starting from cycle I including the preparation stage, implementation stage, observation and reflection. In cycle II, namely planning and implementation, the stages in cycle II are not much different from the stages in cycle I, it's just that the shortcomings in cycle 1 are expected to be corrected in cycle II. The results of this action research indicate that there is an increase in student learning outcomes in physical education subjects from the previous to the first cycle an average of 7.12 and to the second cycle an average of 7.46 with a point difference of 0.34 indicating that the application of game tool modification can improve the learning outcomes of mini volleyball games for class X IPA 2 students at SMA Negeri 1 Pasir, Indragiri Hulu Regency for the 2021/2022 academic year.

Keywords: Mini volleyball game, modification, learning outcomes

\section{PENDAHULUAN}

Pendidikan jasmani olahraga dan kesehatan merupakan bagian penting dari pendidikan secara keseluruhan bertujuan untuk mengembangkan aspek kebugaran jasmani keterampilan gerak, keterampilan berpikir kritis keterampilan sosial, penalaran, stabilitas emosional, tindakan moral, aspek pola hidup sehat dan pengenalan lingkungan bersih melalui aktivitas jasmani, olahraga dan kesehatan terpilih yang direncanakan secara sistematis dalan rangka mencapai tujuan Pendidikan Nasional (Diknas, 2006).

Pendidikan sebagai suatu proses pembinaan manusia yang berlangsung seumur hidup pendidikan jasmani olahraga dan kesehatan yang diajarkan di sekolah memiliki peranan sangat penting, yaitu memberikan kesempatan kepada peserta didik untuk terlibat langsung dalam berbagai pengalaman belajar melalui aktivitas jasmani, olahraga dan kesehatan yang dilakukan secara sistematis. Pembekalan pengalaman belajar itu diarahkan untuk membina pertumbuhan 
fisik dan perkembangan psikis yang lebih baik, sekaligus membentuk pola hidup sehat dan bugar sepanjang hayat Muhajir (2007).

Menurut Winendra (2008) keterampilan teknik dasar permainan bola voli adalah semua gerakan-gerakan yang dibutuhkan dalam permainan bola voli. Teknik dasar permainan bola voli yang diajarkan di kelas X adalah: (1) servis, (2) pasing bawah, (3) pasing atas, (4) smash, dan (5) block. Penyajian permainan bola voli dilakukan oleh pemain-pemain yang semenjak usia dini mendapatkan pendidikan bola voli yang sempurna dan kontiniu, terarah, dan menguasai permainan bola voli. Jadi bagi siswa SMA harus dimulai dari pembinaan teknik dasar, sebab siswa akan berhenti bermain bola voli karena tidak mendapatkan kemajuan dalam penguasaan teknik dasar. Teknik dasar adalah modal utama dalam permainan, yang memungkinkan siswa mencatat sukses.

Dalam pelaksanaan pembelajaran pendidikan jasmani, olahraga, dan kesehatan (penjaskes) khususnya materi permainan bola voli kelas X IPA 2 SMA Negeri 1 Pasir Penyu Kabupaten Indragiri Hulu, banyak kasus yang peneliti temukan. Dalam proses belajar mengajar mengakibatkan siswa mendapatkan pengalaman yang tidak menyenangkan bahkan siswa jera untuk melakukan pembelajaran terutama permainan bola voli. Siswa sering mengeluh kesakitan karena bola yang keras dan tidak memiliki teknik yang benar, sehingga siswa tidak dapat menguasai teknik dasar servis dan pasing dalam permainan bola voli. Sementara servis dan pasing merupakan modal utama dalam permainan bola voli, dengan tidak menguasai teknik dasar bola voli siswa menjadi malas dan tidak berminat lagi bermain bola voli.

Berdasarkan uraian di atas, untuk meningkatkan pendidikan jasmani olahraga dan kesehatan penulis akan membahas salah satu materi pokok yang diajarkan di Sekolah Menegat Atas yaitu permainan bola voli. Permainan bola voli merupakan kegiatan olahraga yang telah merakyat baik di kota bahkan sampai ke pelosok desa. Hal ini juga yang mendasar sehingga permainan bola voli termasuk dalam pembelajaran di Sekolah Menengah Atas.

Oleh karena itu untuk memecahkan permasalahan di atas secara tepat dan akurat diperlukan Penelitian Tindakan Kelas (PTK), berhubung karena keterbatasan dari segi tenaga, pengalaman, waktu, dan dana, maka masalah penelitian berjudul " Permainan bola voli mini dengan modifikasi untuk meningkatkan hasil belajar siswa kelas X IPA 2 di SMA Negeri 1 Pasir Penyu Kabupaten Indragiri Hulu”.

\section{METODE PENELITIAN}

Penelitian ini menggunakan rancangan penelitian tindakan kelas (classroom based action research). Lebih khusus, penelitian ini adalah penelitian tindakan kelas kolaboratif, yaitu kerjasama antara peneliti dengan praktisi di lapangan (guru). Penelitian ini dilakukan di SMA Negeri 1 Pasir Penyu Kabupaten Indragiri Hulu. Pada kelas X IPA 2 SMA dengan jumlah peserta didik 26 orang yang terdiri dari 10 orang laki-laki dan 16 orang perempuan. Penelitian dilakukan selama semester genap Tahun Pelajaran 2021-2022. Peneliti dalam penelitian ini adalah sebagai pelaksana penelitian, pengumpul data, penganalisis data, dan pelapor hasil penelitian. Seorang guru bertindak sebagai observer, dan pengumpul data. Penelitian terdiri atas beberapa siklus, masing-masing siklus melalui tahap perencanaan, pelaksanaan, observasi, dan refleksi tindakan.

Prosedur atau siklus pelaksanaan penelitian tindakan kelas terdiri dari tahap persiapan, pelaksanaan tindakan, observasi, refleksi, sumber dan teknik pengumpulan data, dan teknik analisis data. Pada tahap persiapan atau perencanaan dilakukan berdasarkan pada refleksi awal (observasi pendahuluan) seperti yang telah diuraikan pada latar belakang penelitian. Siklus I direncanakan selama 3 minggu 6 kali pertemuan dengan waktu 2 X 245 menit, dilaksanakan pada semester genap Tahun Pelajaran 2021-2022, dengan menerapkan pembelajaran menggunakan modifikasi. Kompetensi Dasar yang diberikan pada siklus ini adalah bola voli. Proses pembelajaran mengacu pada Rencana Pelaksanaan Pembelajaran yang telah disusun peneliti. Observasi dilaksanakan secara bersamaan dengan pelaksanaan tindakan, yang dilakukan oleh observer. Observasi dilakukan untuk melihat pencapaian yang telah didapatkan 
oleh siswa sejak pembelajaran dengan menggunakan teknik permainan dengan alat modifikasi diterapkan di luar kelas. Fokus observasi adalah bagaimana proses penerapan tindakan yang dilakukan guru dan aktivitas siswa selama proses pembelajaran.

Hasil pembahasan yang diperoleh merupakan refleksi dari apa yang telah terjadi selama penerapan tindakan pada setiap siklus. Hal-hal yang menjadi permasalahan pada tiap siklus dipakai sebagai pertimbangan merumuskan perencanaan tindakan pada siklus berikutnya. Sumber data pada penelitian ini adalah siswa kelas X IPA 2 SMA dengan jumlah murid 26 orang yang terdiri dari 12 orang laki-laki dan 14 orang perempuan. Penelitian dilakukan selama semester genap Tahun Ajaran 2021-2022. Indikator keberhasilan tindakan terhadap peningkatan hasil belajar pada pembelajaran bola voli dengan menggunakan alat modifikasi siswa Kelas X IPA 2 di SMA Negeri 1 Pasir Penyu Kabupaten Indragiri Hulu dapat dilihat dengan pencapaian hasil belajar minimal 70\% siswa di atas nilai 7,0, nilai kriteria ketuntasan minimal bidang studi Penjaskes. Kriteria Ketuntasan dengan nilai besar dan sama dari 7,0 dikatakan tuntas dan di bawah 7,0 dikatakan belum tuntas.

\section{HASIL DAN PEMBAHASAN}

Penelitian yang dilaksanakan dengan menggunakan modifikasi alat ini dilakukan pada siswa kelas X IPA 2 di SMA Negeri 1 Pasir Penyu Kabupaten Indragiri Hulu khusus mata pelajaran penjasorkes Tahun Pelajaran 2021-2022, dengan jumlah siswa 26 orang yang terdiri 12 orang laki-laki dan 14 orang perempuan. Penelitian dilakukan pada materi keterampilan teknik dasar permainan bola voli mini .

Hasil

\section{Siklus I}

\section{a. Tahap Persiapan}

Pada siklus pertama pertemuan pertama peneliti mempersiapkan pembuatan silabus yang dilakukan dengan cara mengumpulkan kurikulum yang akan digunakan, buku pedoman dan buku penunjang sebagai panduan perencanaan dalam pembuatan silabus.

\section{b. Tahap Pelaksanaan}

Pada siklus pertama kegiatan pembelajaran yang di kelola berdasarkan Rencana Pelaksanaan Pembelajaran, pada proses pembelajaran di awali dengan mengucapkan salam dan melihat kehadiran siswa dengan cara mengabsen masing-masing siswa, penjelasan dan tujuan pembelajaran serta penggunaan modifikasi alat permainan yang akan dilakukan dalam setiap proses pembelajaran sesuai dengan materi yang diajarkan yaitu teknik dasar permainan bola voli mini, pada kegiatan awal dilakukan dengan persepsi memperkenalkan materi pembelajaran serta memotivasi siswa dengan cara pengulangan materi sebelumnya dan menggaitkan materi yang akan diajarkan sesuai dengan permainan bola voli mini.

Selanjutnya pada kegiatan inti, peneliti menjelaskan secara singkat tentang materi pelajaran. kemudian dilanjutkan dengan menentukan jenis modifikasi alat permainan yang sesuai untuk materi pelajaran yang dilakukan dengan cara merencanakan lapangan ukuran kecil, bola voli mini ukuran mini, dan pemain dengan jumlah kecil yang sudah dipersiapkan peneliti sebelumnya. Seiring dengan penjelasan guru, siswa mengamati dan memperhatikan penjelasan guru tentang bagaimana penggunaan modifikasi alat dalam permainan bola voli mini. Pada akhir kegiatan siswa mencatat kesimpulan materi pembelajaran sebagai catatan untuk dipelajari di rumah dan sebagai arsip kelas dan kemudian siswa mengerjakan latihan permainan teknik dasar bola voli mini yang telah dipersiapkan oleh guru.

\section{c. Tahap Observasi}

Berdasarkan pengamatan observer pada siswa siklus pertama pertemuan pertama dan kedua secara umum siswa masih bingung dengan metode pembelajaran menggunakan modifikasi alat, untuk aktivitas siswa secara umum belum menunjukkan hasil yang baik. Mengerjakan tugas yang diberikan guru juga masih belum memahami, 
masih kurang menunjukkan kemajuan, ini disebabkan siswa masih tergantung pada penjelasan guru secara optimal.

Kegiatan belajar siswa di dukung oleh hasil observasi aktivitas siswa yang di ukur dari 4 komponen pada siklus pertama aktivitas siswa mencapai $74,04 \%$ dari yang di harapkan guru.

Distribusi kegiatan siswa siklus pertama pertemuan pertama dapat dilihat pada Tabel 1 sebagai berikut:

Tabel 1. Kegiatan Siswa Siklus 1

\begin{tabular}{llll}
\hline No & Item Observasi & Frekwensi & Presentase \\
\hline 1 & $\begin{array}{l}\text { Melakukan servis } \\
\text { Melakukan passing } \\
\text { bawah }\end{array}$ & 23 & 88,46 \\
& $\begin{array}{l}\text { Melakukan passing } \\
\text { atas }\end{array}$ & 21 & 80,77 \\
& $\begin{array}{l}\text { Melakukan smash } \\
\text { dan block }\end{array}$ & 13 & 76,92 \\
\hline & $\begin{array}{l}\text { Jumlah } \\
\text { Rata-rata } \\
\text { presentase }\end{array}$ & 77 & 50,00 \\
\hline
\end{tabular}

Hasil pengamatan aktivitas guru apabila dianalisis lebih jauh dan didiskusikan dengan observer ditemukan beberapa kekuatan dan kelemahan sebagai berikut; guru sudah tepat menentukan jenis modifikasi sarana atau alat, guru sudah memperhatikan dan memperhitungkan kondisi siswa dengan tepat, hanya saja guru kurang tepat dalam menyajikan modifikasi alat permainan sesuai dengan materi teknik dasar permainan bola voli mini. Sedangkan mendemonstrasikan atau memperlihatkan modifikasi keterampilan permainan bola voli mini pada waktu dan situasi yang tepat guru sudah sempurna. Hasil aktivitas guru secara keseluruhan mencapai sempurna dengan skor 23 dengan skor yang diharapkan 25.

Distribusi penyebaran aktivitas guru dapat dilihat pada Tabel 2 sebagai berikut:

Tabel 2. Distribusi Aktivitas Guru Siklus 1

\begin{tabular}{llccc}
\hline No & Klasifikasi & Frekwensi & Skor Standar & Skor \\
\hline 1 & Sangat Sempurna & 3 & 5 & 15 \\
2 & Sempurna & 2 & 4 & 8 \\
3 & Cukup Sempurna & 0 & 3 & 0 \\
4 & Kurang Sempurna & 0 & 2 & 0 \\
\hline 5 & Tidak Sempurna & 0 & 1 & 0 \\
\hline & Jumlah & & & 23
\end{tabular}

\section{d. Tahap Refleksi}

Berdasarkan pengamatan dan hasil diskusi bersama observer ada beberapa hasil refleksi yang terdapat dikemukakan. Hasil aktivitas guru dalam penerapan modifikasi alat dalam permainan bola voli mini belum melaksanakan dengan sempurna, hal ini sesuai dengan hasil pengamatan dimana aktivitas guru, hal ini disebabkan guru belum menguasai sepenuhnya dengan pemanfaatan modifikasi alat dalam pembelajaran bola voli mini. 
Tabel 3. Analisis Hasil Belajar Siswa pada Siklus I

\begin{tabular}{ll}
\hline Item Analisis & Nilai \\
\hline Jumlah Siswa & 26 \\
\hline Rata-rata & 7,12 \\
Minimum & 6 \\
Maximum & 9 \\
Jumlah & 185 \\
\hline
\end{tabular}

Tabel 4. Distribusi data Hasil Belajar Siswa Siklus I

\begin{tabular}{ccccc}
\hline Nilai & Frekwensi & Persentase & $\begin{array}{c}\text { Validitas } \\
\text { precentase }\end{array}$ & $\begin{array}{c}\text { Kumulatif } \\
\text { presentase }\end{array}$ \\
\hline 6,00 & 9 & 34,6 & 34,6 & 34,6 \\
7,00 & 8 & 30,8 & 30,8 & 65,4 \\
8,00 & 6 & 23,1 & 23,1 & 88,5 \\
9,00 & 3 & 11,5 & 11,5 & 100,0 \\
Total & 26 & 100,0 & 100,0 & \\
\hline
\end{tabular}

SIKLUS1

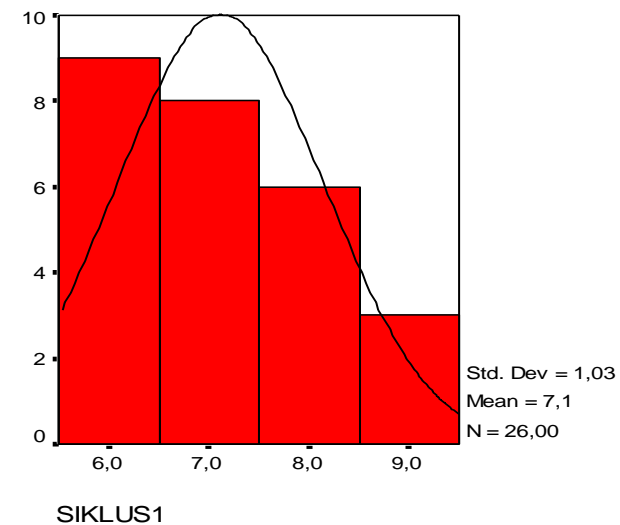

\section{Gambar 1. Histogram Hasil Belajar Siswa Siklus I}

Memperhatikan deskripsi proses pembelajaran yang dikemukakan di atas dan melihat hasil belajar siswa pada mata pelajaran penjasorkes, maka berdasarkan hasil pembahasan peneliti dan obsever terhadap perbaikan pembelajaran pada siklus pertama, terdapat beberapa kekuatan dan kelemahan pembelajaran. Berdasarkan hasil refleksi dan hasil belajar bola voli mini pada siklus pertama perlunya perbaikan yang lebih terhadap penerapan modifikasi alat dalam permainan bola voli mini pada siklus kedua.

\section{Siklus II}

\section{a. Tahap Persiapan}

Pada siklus kedua pertemuan satu dan kedua peneliti mempersiapkan pembuatan silabus yang dilakukan dengan cara mengumpulkan kurikulum yang akan digunakan, buku pedoman dan buku penunjang sebagai panduan perencanaan dalam pembuatan silabus.

\section{b. Tahap Pelaksanaan}

Pada siklus kegiatan pembelajaran yang di kelola berdasarkan Rencana Pelaksananya Pembelajaran, pada proses pembelajaran di awali dengan memberi salam dan melihat kehadiran siswa, penjelasan dan tujuan pembelajaran serta penggunaan modifikasi alat permainan yang akan dilakukan dalam setiap proses pembelajaran sesuai dengan materi yang diajarkan, pada kegiatan awal dilakukan dengan persepsi 
memperkenalkan materi pembelajaran serta motivasi siswa melalui pengulangan materi sebelumnya dan menggaitkan materi yang akan diajarkan sesuai dengan keterampilan teknik dasar permainan bola voli mini.

Selanjutnya peneliti melanjutkan pelajaran dengan cara menyajikan modifikasi alat permainan dengan tepat sesuai dengan materi yang diajarkan tentang keterampilan teknik dasar permainan bola voli mini, dengan cara menentukan ukuran lapangan, bola, dan jumlah pemain dengan ukuran kecil. Adapun alat-alat yang digunakan adalah lapangan, bola voli mini, dan jumlah pemain dengan ukuran mini yang sesuai dengan materi pelajaran. Setelah sarana pendukung yang telah dipersiapan, siswa disuruh mengamati dan memperhatikan secara seksama materi keterampilan teknik dasar permainan bola voli mini yang dijelaskan peneliti, dilanjutkan siswa di minta untuk merespon tentang keterampilan teknik permainan bola voli mini yang telah dijelaskan, kemudian guru melanjutkan materi pelajaran dengan cara mencobakan masing-masing teknik dasar permainan bola voli mini, seperti servis, pasing bawa, pasing atas, smash, dan block, seterusnya anak mendengarkan dan memperhatikan keterangan dan peragaan peneliti.

Pada akhir kegiatan siswa mencatat kesimpulan materi pembelajaran sebagai catatan untuk dipelajari dirumah dan sebagai arsip kelas dan kemudian siswa mengerjakan latihan soal yang telah dipersiapkan oleh guru.

\section{c. Tahap Observasi}

Berdasarkan pengamatan observer pada siswa siklus II, siswa sudah terbiasa dengan metode pembelajaran menggunakan modifikasi alat permainan, untuk aktivitas siswa secara sudah menunjukkan hasil yang baik. Namun beberapa aspek seperti; mengamati dan memperhatikan peragaan guru, merespon pertanyaan guru terlihat siswa sudah terbiasa dengan pembelajaran yang dilaksanakan.

Pada aktivitas siswa pada waktu penerapan modifikasi alat permainan terlihat siswa sudah familiar dan meningkatnya kepercayaan pada kemampuan yang dimiliki pada saat menerima penjelasan dari guru.

Hasil belajar siswa ini didukung oleh hasilobservasi aktivitas siswa yang diukur dari 4 komponen pada siklus kedua aktivitas siswa mencapai 85,58 \% diharapkan guru.

Distribusi kegiatan siswa siklus kedua pertemuan kedua dapat dilihat pada Tabel 5 sebagai berikut:

Tabel 5. Distribusi Kegiatan Siswa Siklus 2

\begin{tabular}{llcc}
\hline No & \multicolumn{1}{c}{ Item Observasi } & Frekwensi & Presentase \\
\hline $\mathbf{1}$ & Melakukan servis & 25 & 96,15 \\
2 & Melakukan Pasing bawah & 24 & 92,31 \\
3 & Melakukan pasing atas & 22 & 84,62 \\
4 & Melakukan smash dan block & 18 & 69,23 \\
\hline & Jumlah & 89 & \\
& Rata-rata presentase & & $\mathbf{8 5 , 5 8}$ \\
\hline
\end{tabular}

Hasil pengamatan aktivitas guru apabila dianalisis lebih jauh dan didiskusikan dengan observer, ditemukan beberapa kekuatan sebagai berikut; guru sudah tepat menentukan jenis modifikasi alat permainan, guru sudah memperhatikan dan memperhitungkan kondisi siswa dengan tepat, guru sudah tepat dalam menyajikan modifikasi alat modifikasi sesuai dengan materi keterampilan teknik dasar permainan bola voli mini. Sedangkan menempatkan atau memperlihatkan modifikasi alat permainan pada waktu dan situasi yang tepat guru sudah sangat sempurna artinya peneliti sudah menyesuaikan materi yang disampaikan dengan modifikasi alat permainan yang disesuaikan. 
Tabel 6. Distribusi Aktivitas Guru Siklus 2

\begin{tabular}{clccc}
\hline No & \multicolumn{1}{c}{ Klasifikasi } & Frekwensi & Skor Standar & Skor \\
\hline 1 & Sangat Sempurna & 4 & 5 & 20 \\
2 & Sempurna & 1 & 4 & 4 \\
3 & Cukup Sempurna & 0 & 3 & 0 \\
4 & Kurang Sempurna & 0 & 2 & 0 \\
5 & Tidak Sempurna & 0 & 1 & 0 \\
\hline & Jumlah & & & 24
\end{tabular}

\section{d. Tahap Refleksi}

Berdasarkan pengamatan dan hasil diskusi bersama observer ada beberapa hasil refleksi yang terdapat dikemukakan. Hasil aktivitas guru dalam penerapan modifikasi alat sudah melaksanakan dengan sempurna, hal ini sesuai dengan hasil pengamatan dimana aktivitas guru, hal ini disebabkan guru dan siswa sudah menguasai sepenuhnya dengan pemanfaatan modifikasi alat permainan dalam pembelajaran bola voli mini.

Berdasarkan hasil tes performance belajar siswa yang di lakukan pada siklus kedua di peroleh rata-rata hasil belajar siswa pada permainan bola voli mini 7,46, nilai tertinggi 9,00, nilai terendah 6,00. Apabila dilihat distribusi atau 7,69\%. (Ketuntasan secara induvidual 100\%). Deskripsi data hasil belajar siswa siklus 2 sebagai berikut:

Tabel 7. Analisis Hasil Belajar Siswa pada Siklus II

\begin{tabular}{cc}
\hline Item Analisis & Nilai \\
\hline Jumlah Siswa & 26 \\
Rata-rata & 7,46 \\
Minimum & 6 \\
Maximum & 9 \\
\hline Jumlah & 194
\end{tabular}

Tabel 8. Distribusi data Hasil Belajar Siswa Siklus

\begin{tabular}{ccccc}
\hline Nilai & Frekwensi & Persentase & $\begin{array}{c}\text { Validitas } \\
\text { precentase }\end{array}$ & $\begin{array}{c}\text { Kumulatif } \\
\text { precentase }\end{array}$ \\
\hline 6,00 & 2 & 7,7 & 7,7 & 7,7 \\
7,00 & 13 & 50,0 & 50,0 & 57,7 \\
8,00 & 8 & 30,8 & 30,8 & 88,5 \\
9,00 & 3 & 11,5 & 11,5 & 100,0 \\
\hline Total & 26 & 100,0 & 100,0 & \\
\hline
\end{tabular}

SIKLUS2

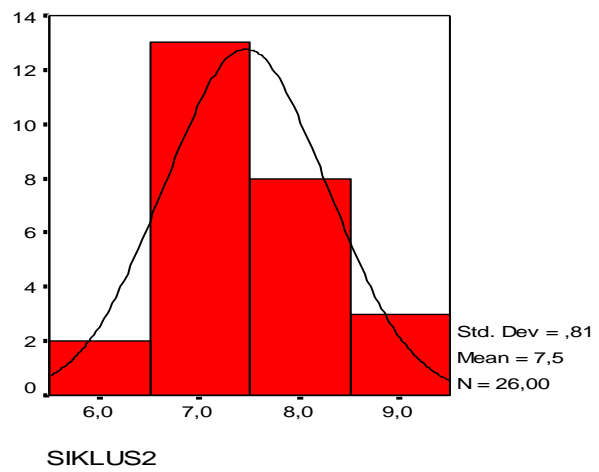

Gambar 2. Histogram Hasil Belajar Siswa Siklus II 


\section{EDUCATIONAL : Jurnal Inovasi Pendidikan dan Pengajaran Vol. 2 No. 1 Februari 2022 e-ISSN : 2775-2593 | p-ISSN : 2775-2585}

voli mini ini telah mencapai ketuntasan kelas rata-rata 7,46, pencapaian ketuntasan induvidu, yang mana sebesar 92,31\% dari siswa prestasi belajar di atas rata-rata 7,0.

\section{Pembahasan}

Nana Sujana (2001:39) mengungkapkan bahwa hasil belajar siswa di sekolah 70\% dipengaruhi oleh kemampuan siswa dan 30\% dipengaruhi oleh lingkungan. Berkaitan dengan faktor dari dalam siswa, selain faktor kemampuan ada juga faktor lain yaitu: motivasi, minat, perhatian, sikap, kebiasaan belajar, keturunan, kondisi sosial fisik dan psikis. Salah satu faktor lingkungan yang paling dominan mempengaruhi hasil belajar adalah kualitas pengajaran. Yang dimaksud dengan kualitas pengajaran adalah tinggi rendahnya atau efektif tidaknya proses pembelajaran dalam mencapai tujuan instruksional. Bahwa ada tiga variabel utama dalam teori utama di sekolah, yaitu karakteristik individu, kualitas pengajaran dan hasil belajar siswa.

Dari hasil penelitian pada siklus pertama menunjukkan hasil belajar dan keterampilan teknik dasar permainan bola voli mini belum mencapai indikator yang ditetapkan (belum tercapainya ketuntasan individual). Hal ini disebabkan pengelolaan pembelajaran pada siklus pertama yang belum optimal seperti: (a) pengelolaan pembelajaran oleh peneliti telah sesuai dengan tahapan yang dimuat dalam Rencana Pelaksanaan Pembelajaran (RPP), namun penerapan modifikasi alat dalam proses pembelajaran guru masih mengalami beberapa kelemahan khususnya dalam hal penyajian materi kurang sistematis, kurang serius dalam membimbing, kurang memberikan penghargaan bagi siswa yang berhasil, serta tidak meratanya pertanyaan yang diberikan kepada siswa, (b) motivasi dan keantusian siswa mengikuti pembelajaran cukup baik, (c) secara umum aktivitas siswa dalam belajar sudah mulai terfokus pada tugas-tugas belajar, namun masih perlu pengawasan yang lebih ketat dan mendidik, (d) hasil belajar siswa setelah perbaikan pembelajaran lebih baik, jika dibandingkan dengan hasil belajar siswa sebelum tindakan, (e) kemandirian siswa dalam membangun pengetahuannya belum optimal, karena siswa belum terbiasa, (f) siswa masih malu untuk mengemukakan ideidenya baik saat mengerjakan tugas-tugas.

Kondisi ini menyebabkan siswa kurang aktif baru mencapai 74,04 \% yang disebabkan masih rendahnya ketekunan siswa, untuk menanyakan kesulitan, mencatat, dan membantu pemahaman materi. Hal ini menunjukkan bahwa proses pembelajaran yang dibawakan peneliti masih perlu perencanaan yang lebih baik dengan memperhatikan kelemahan dan kekuatan yang telah teridentifikasi pada siklus pertama sebagai dasar perbaikan siklus kedua.

Selanjutnya, adanya peningkatan hasil belajar siswa pada mata pelajaran Penjaskes dari sebelumnya ke siklus pertama rata-rata 7,12 dan ke siklus kedua rata-rata 7,46 dengan silisih point sebesar 0,34 menunjukkan bahwa penerapan modifikasi alat permainan dapat meningkatkan hasil belajar permainan bola voli mini siswa kelas X IPA 2 di SMA Negeri 1 Pasir Kabupaten Indragiri Hulu Tahun Pelajaran 2021/2022.

\section{KESIMPULAN}

Penerapan modifikasi alat permainan dapat meningkatkan hasil belajar permainan bola voli mini siswa pada mata pelajaran penjaskes siswa kelas X IPA 2 di SMA Negeri 1 Pasir Kabupaten Indragiri Hulu Tahun Ajaran 2021-2022. Dengan penerapan prinsip-prinsip modifikasi alat permainan bola voli mini dengan efektif dalam proses pembelajaran dapat meningkatkan keterampilan teknik dasar permainan bola voli mini dan hasil belajar siswa pada mata pelajaran penjaskes siswa kelas X IPA 2 di SMA Negeri 1 Pasir Kabupaten Indragiri HuluTahun Ajaran 2021-2022. Keberhasilan ini disebabkan dengan penerapan modifikasi alat aktivitas siswa menjadi aktif. Berarti siswa cenderung positif dalam mengikuti proses belajar mengajar yang diberikan guru maupun dalam melakukan permainan serta tanya jawab di luar kelas. Dengan kondisi tersebut tingkat penerimaan siswa akan meningkat dan pada gilirannya dapat meningkatkan keterampilan teknik dasar permainan bola voli mini dan hasil belajar siswa. Dengan penerapan prinsip-prinsip penerapan modifikasi alat permainan yang efektif dalam 
pembelajaran dapat memperbaiki pola pembelajaran dan dapat meningkatkan keterampilan teknik dasar permainan bola voli mini dan hasil belajar siswa.

\section{DAFTAR PUSTAKA}

Adi, Winendra, dkk. 2008. Seri Olahraga Atletik. Yogyakarta: PT Pustaka Insan Madani Arikunto, Suharsimi. 2006.Prosedur Penelitian Suatu Pendekatan Praktik. Jakarta: PT Rineka Cipta

Carr, Gery A. 2003. Atletik Untuk Sekolah. Jakarta: PT Raja Grafindo Persada Ismaryati. 2008. Tes dan Pengukuran Olahraga. Surakarta: LPP UNS dan UPT UNS

Kokasih, Engkos. 1993. OLahraga Teknik dan Program Latihan .Jakarta: Akademi Pressindo Marchamah. 2009. Ensiklopedia Olahraga Atletik. Semarang: PT Bengawan Ilmu Muhajir. 2007. Pendidikan Jasmani Olahraga dan Kesehatan. Jakata: Erlangga Sudijono, Anas. 2012. Pengantar Statistik pendidikan. Jakarta: PT Raja Grafindo Persada Undang-Undang RI Nomor 3 Tahun 2005 Tentang Sistem Keolahragaan Nasional. 2007. Bandung: Citra Umbara 